Original Research Article

\title{
Spectrum of infectious dermatoses in pediatric population attending tertiary care centers in Central India: an observational study
}

\author{
Shah A. ${ }^{1}$, Sharma P. ${ }^{2}$, Bhati S.S. ${ }^{3}$, Tomar A. ${ }^{4}$, Jain S. ${ }^{5}$ \\ ${ }^{1}$ Dr. Akhil Shah, Associate Professor, Amaltas Institute of Medical Sciences, Dewas, Madhya Pradesh, ${ }^{2}$ Dr. Parikshit Sharma, \\ Professor, ${ }^{3}$ Dr. Surendra Singh Bhati, Associate Professor, ${ }^{4}$ Dr. Anushtha Tomar, PG Resident, ${ }^{5}$ Dr. Shubhang Jain, PG \\ resident; $2,3,4,5$ authors are affiliated with Index Medical College, Hospital \& Research Centre, Indore, Madhya Pradesh, India.
}

Corresponding Author: Dr. Surendra Singh Bhati, Associate Professor, Index Medical College, Hospital \& Research Centre, Indore. E-mail: drssbhati13@gmail.com

\begin{abstract}
Background: Pediatric infectious dermatoses are distinct group of disorders, comprising of skin problems encountered during childhood and adolescence. There is variation in the pattern and presentation of dermatoses in childhood compared to adults. Aims \& Objectives: To determine the prevalence and clinical characteristics of different infectious pediatric dermatoses in rural tertiary care centers in central India. Materials \&Methods: This is a cross-sectional study of infectious dermatoses in pediatric patients attending DVL OPD of tertiary care centers, Index Medical College Hospital \& Research Center, Indore (M.P.) \& Amaltas Institute of Medical Sciences, Dewas (M.P.) between JULY 2018toNOV 2019. Results: There were 106 boys and 94 girls in total 200 study populations. Over all most common infections in the present study were Molluscum contagiosum (14.5\%), Pityriasis versicolor (14\%) and Tinea corporis (14\%). Majority of the infectious skin conditions were Fungal infections (48\%) among which most common was dermatophytosis $(58.33 \%$ of fungal infections) followed by Pityriasis versicolor (29.16\% of fungal infections). Viral infections comprised of $37 \%$ of all infections among which the most common is Molluscum contagiosum (39.1\%) followed by Viral warts $(21.6 \%)$ and Pityriasis rosea (14.86\%). Bacterial infections were $15 \%$ of all the infections. Most common bacterial infection was Furunculosis (30\%) followed by Impetigo $(23.33 \%)$ and Secondary pyoderma (20\%). Conclusion: The present study was aimed at studying the spectrum of infectious dermatoses in pediatric population in a rural health setup. The present study showed upward trend in fungal infections and downward trend in bacterial infections.
\end{abstract}

Keywords: Dermatoses, Pediatric, Infectious

\section{Introduction}

Skin diseases are a major health problem in the pediatric age group and are associated with significant morbidity. Skin diseases constitute $30 \%$ of all outpatient visit to a pediatrician and $30 \%$ of all visits to a dermatologist involve children $[1,2]$.

Due to anatomical differences, certain diseases occur in the childhood while many occur rarely at this time. Because of more delicate nature of the skin of infant and children as well as constant exposure to trauma, most skin diseases of childhood are attributable to physical causes, infections and allergy. The prevalence of skin diseases among children in various parts of India ranges from $8.7 \%$ to $35 \%$ [3]. Dermatologic conditions constitute at least $30 \%$ of all outpatient visits to pediatricians and $30 \%$ of all visits to dermatologists involve children $[4,5]$.

Manuscript received: $30^{\text {th }}$ October 2019

Reviewed: $10^{\text {th }}$ November 2019

Author Corrected: $15^{\text {th }}$ November 2019

Accepted for Publication: 19 $9^{\text {th }}$ November 2019
The incidence of various dermatologic conditions varies according to age, race, geographic locations, climate, nutrition, hygiene, socio-economic conditions and heredity $[6,7,8,9]$.

As the age advances, the skin matures, immune response of the body develops and a child receives vaccination for various infectious diseases. If there's a dysfunction at any of these, the child gets more prone to infections. Various epidemiological studies have been undertaken across the world including India to study the pattern of pediatric dermatoses.

The pattern of skin diseases in India is different across the states, rural and urban areas, and hilly areas. The present study was conducted to assess the pattern of various infectious dermatoses in pediatric patients along with prevalence, in rural tertiary health care centers. 


\section{Original Research Article}

\section{Materials and Methods}

Study was conducted on 200 children with infectious dermatoses aged below 14 years attending the Dept. Of D.V.L, Index Medical College Hospitaland Research Center, Indore and Amaltas Institute of Medical Sciences, Dewas (M.P.).

Inclusion criteria: All clinically diagnosed cases of infectious dermatoses aged below 14 years of age attending outpatient department were included.
Data collection: Informed valid written consent was taken from parents and clinical data was recorded as per the proforma. Detailed history taken and complete clinical examination was done. All these patients were subjected to routine investigations and special investigations were done whenever necessary. All patients were divided into 3 groups: $<1$ month (neonate), 1 month-5 years (toddler), 5 years - 14 years (school going). It was a hospital based cross sectional and clinical observational study conducted between July 2018 to October 2019.

\section{Results}

200 cases were studies which showed a male preponderance (53\%) (Table 1). Overall most common infections in the present study were Molluscum contagiosum (14.5\%), Pityriasis versicolor (14\%) and Tinea corporis (14\%). Majority of the infectious skin conditions were Fungal infections (48\%) among which most common was dermatophytosis (58.33\% of fungal infections) followed by Pityriasis versicolor (29.16\% of fungal infections). Viral infections comprised of $37 \%$ of all infections among which the most common is Molluscum contagiosum (39.1\%) followed by Viral warts (21.6\%) and Pityriasis rosea (14.86\%). Bacterial infections were $15 \%$ of all the infections. Most common bacterial infection was Furunculosis (30\%) followed by Impetigo (23.33\%) and Secondary pyoderma (20\%). The number of cases divided through age distribution is represented through Table 2 .

Most of the skin conditions in neonates were candidiasis $(40.9 \%)$ and tinea capitis $(9.09 \%)$. In $>1$ month to 14 years age group of children among infectious disorders, children were found to be affected most by Molluscum contagiosum (14.5\%), Tinea corporis (14\%), Pityriasis versicolor (14\%), Tinea cruris $(8.5 \%)$, Viral warts (8\%), Candidiasis $(6 \%)$, Pityriasis rosea $(5.5 \%)$, and chicken pox $(5 \%)$

Table No.-1: Sex distribution.

\begin{tabular}{|c|c|c|}
\hline Patients & Number & Percentage (\%) \\
\hline Male & 106 & 53 \\
\hline Female & 94 & 47 \\
\hline Total & $\mathbf{2 0 0}$ & $\mathbf{1 0 0}$ \\
\hline
\end{tabular}

Table No.-2: Age distribution.

\begin{tabular}{|c|c|c|}
\hline Age & Number & Percentage (\%) \\
\hline Neonate-1 month & 22 & 11 \\
\hline 1 month-5 years & 70 & 35 \\
\hline 5 years-14 years & 108 & 54 \\
\hline
\end{tabular}

Table-3: Spectrum of diseases.

\begin{tabular}{|c|c|c|}
\hline Category & Number & Percentage (\%) \\
\hline Fungal infections & 96 & 48 \\
\hline Viral infections & 74 & 37 \\
\hline Bacterial infections & 30 & 15 \\
\hline
\end{tabular}

In the study, fungal infections were most common, comprising $48 \%$ of all the infectious dermatoses. Viral infections and bacterial infections comprised of $37 \%$ and $15 \%$ respectively (Table 3 ).

Among the fungal infections, dermatophytic infections were the most common (57.5\%) followed by Pityriasis versicolor (29.16\%) and Candidiasis (12.5\%) (Table 4). 


\section{Original Research Article}

Table-4: Distribution of fungal infections.

\begin{tabular}{|c|c|c|}
\hline Fungal infections & Number & Percentage (\%) \\
\hline Tinea corporis & 28 & 29.16 \\
\hline Tinea cruris & 17 & 17.08 \\
\hline Tinea capitis & 7 & 7.2 \\
\hline Tinea faciei & 4 & 4.1 \\
\hline Pityriasis versicolor & 28 & 29.16 \\
\hline Candidiasis & 12 & 12.5 \\
\hline Total & $\mathbf{9 6}$ & $\mathbf{1 0 0}$ \\
\hline
\end{tabular}

Among the viral infections, most common infections were Molluscum contagiosum (39.1\%), viral warts (21.6\%), Pityriasis rosea (14.86\%) and Chicken pox (13.5\%) (Table 5).

Table-5: Distribution of viral infections.

\begin{tabular}{|c|c|c|}
\hline Viral infections & Number & Percentage (\%) \\
\hline Molluscum contagiosum & 29 & 39.1 \\
\hline Warts & 16 & 21.6 \\
\hline Pityriasis rosea & 11 & 14.86 \\
\hline Chicken pox & 10 & 13.5 \\
\hline Viral Exanthem & 5 & 6.66 \\
\hline Herpes simplex and zoster & 3 & 4.05 \\
\hline Total & $\mathbf{7 4}$ & $\mathbf{1 0 0}$ \\
\hline
\end{tabular}

Furunculosis $(30 \%)$ was the most common bacterial infection in the study followed by Impetigo (23.33\%), secondary pyoderma (20\%), SSSS (10\%) and pitted keratolysis (6.6\%) (Table 6).

Table-6: Distribution of bacterial disease.

\begin{tabular}{|c|c|c|}
\hline Bacterial infections & Number & Percentage (\%) \\
\hline Furunculosis & 9 & 30 \\
\hline Impetigo & 7 & 23.33 \\
\hline Secondary pyodermas & 6 & 10 \\
\hline SSSS & 3 & 3.33 \\
\hline Pitted keratolysis & 1 & 3.33 \\
\hline Intertrigo & 1 & 3.33 \\
\hline Congenital syphilis & 1 & 3.33 \\
\hline Leprosy & 1 & 3.33 \\
\hline TBVC & 1 & $\mathbf{1 0 0}$ \\
\hline Total & $\mathbf{3 0}$ & 20 \\
\hline
\end{tabular}

\section{Discussion}

Skin diseases are a major health problem in the pediatric age group and are associated with significant morbidity. Skin diseases in the pediatric age group can be transitory or chronic and recurrent. Cutaneous infections are common in children during school going years. Skin problem in children during the first few weeks of life can raise concern, even for experienced of neonatologists and pediatric dermatologists.
The skin of a newborn infant differs from adult skin in several ways that place the infants at increased risk for thermal instability, skin damage, percutaneous infection and toxicity from topically applied agents [10]. Hot and humid climate of a developing nation are more prone to infectious dermatoses. Poor sanitation and low socioeconomic status also may be an important factor for increased prevalence of pediatric infectious dermatoses. 


\section{Original Research Article}

Majority of the skin conditions in neonates were candidiasis (40.9\%) and tinea capitis (9.09\%). In $>1$ month to 14 years age group of children among infectious disorders, children were found to be affected most by Molluscum contagiosum (14.5\%), Tinea corporis (14\%), Pityriasis versicolor $(14 \%)$, Tinea cruris $(8.5 \%)$, Viral warts (8\%), Candidiasis (6\%), Pityriasis rosea (5.5\%), and chicken pox $(5 \%)$.

There was variation in prevalence of infectious dermatosis among the age groups in the present study. In the neonatal age and 5 years-14 years age group (school going children) fungal infections were predominantly seen while in the $>1$ month-5 years group (toddler) bacterial infections were the most common group of infections seen followed by fungal infections.

Overall in the study, bacterial infections constituted $15 \%$ of the total infections compared to other study like Patel et al. (24.90\%) [11] and Thappa (25.64\%). [1]. Furunculosis was the most common bacterial infection with $30 \%$ of total bacterial infections, followed by impetigo with $23.33 \%$, then secondary bacterial infections with $20 \%$ of bacterial infections. Pyodermas were the single most common dermatoses found out by Bhatia [12] and Ghosh et al. [13]

Fungal infections of the skin constituted $48 \%$ of the total infections. Dermatophytic infections were the most common among these infections making up to $58.33 \%$. Tinea corporis was found in a significant number of children forming $50 \%$ of dermatophytic infections and $29.3 \%$ of all fungal infections followed by Tinea cruris. These findings supported by other studies like Patel et al. (7.81\%) [11] Thappa (8.49\%), [1] Sharma [14] and Ben Saif and Al Shehab [15].

Pityriasis versicolor was seen in $29.16 \%$ of total fungal infections. The incidence varied from 3.3 to 8.5 in various other studies. [16,17,18] Among candidal infections, which constituted $12.5 \%$ of the fungal infections. Karthikeyan et al.'s study was similar to us which showed candida infections constituted $2.1 \%$ of total dermatoses [17].

The viral infections constituted $37 \%$ of the total infections. Molluscum contagiosum was the most common viral disease constituting $39.1 \%$ of these infections. Karthikeyan et al. in their study observed that incidence of molluscum contagiosum was $2.5 \%$ in children aged 1 to 15 [17]. Second most common viral infection in the present study was Warts, which constituted $21.6 \%$ of viral infections. It was observed that viral warts were more common in the adolescent group, similar to observations in previous studies $[11,19]$. Similar to findings observed by the study of Sharma and Mendiratta [14]. While studies of Patel (1.53\%), [11] and in countries like Turkey, Switzerland, recently in Taiwan and Nigeria where the higher incidence of warts in children were found. [4,20,21,22]. Pityriasis rosea was the next common viral infection with $14.8 \%$ of viral infections. Hand foot mouth disease constituted $5.4 \%$ of viral infections.

The incidence of Varicella was 5\% in the present study which was similar to that reported by Karthikeyan et al [17]. The incidence of Herpes simplex viral infection was $1.5 \%$ in the present study whereas in Karthikeyan et al. study, it was $0.37 \%$ [17]. Scarlet fever constituted $0.5 \%$ of all the infections.

\section{Conclusion}

The present study was aimed at studying the spectrum of infectious dermatoses in pediatric population in a rural health setup. The present study showed upward trend in fungal infections due to host related factors which is transferred to children due to contact. The study also showed downward trend in bacterial infections which is corroborating with the society trend due to better availability of antibiotics and better reach of hospital setups in rural population. More number of large population-based studies are required for the accurate findings.

Limitation of the study: The study was conducted in Central India and was on small sample size and may not represent the entire country.

\section{What does this study add to existing knowledge?}

This study adds to the trend of infectious skin diseases in Central India and highlights the rise of fungal infections in pediatric population.

\section{Author's contribution}

- Dr. Akhil Shah: Main Author, Principal investigator, Data collection, Data analysis

- Dr. Parikshit Sharma: Co-author, Co-investigator, Data collection, Data analysis

- Dr. Surendra Singh Bhati: Corresponding author, Coinvestigator, Data collection

- Dr. Anushtha Tomar: Data collection

- Dr. Shubhang Jain: Data collection

Funding: No funding sources

Conflict of interest: None declared

Ethical Approval: This study was approved by the Institutional Ethics Committee 
Original Research Article

\section{References}

1.Thappa DM. Common skin problems in children. Indian J Pediatr. 2002;69(8):701-706.

2. Federman DG, Reid MC, Feldman SR, Greenhoe J, Kirsner RS. The primary care provider and the care of skin disease. Arch Dermatol. 2001;137(1):25-29. doi:10.1001/ archderm.137.1.25.

3. Sharma NK, Garg BK, Goel M. Pattern of skin diseases in urban school children. Indian J Dermatol Venereol Leprol. 1986;52(6):330-331.

4. Wisuthsarewong W, Viravan S. Analysis of skin diseases in a referral pediatric dermatology clinic in Thailand. J Med Assoc Thai. 2000;83(9):999-1004.

5. Serarslan G, Savas N. Prevalence of skin diseases among children and adolescents living in an orphanage in Antakya, Turkey. Pediatr Dermatol. 2005;22(5):490-492. doi: https://doi.org/10.1111/j.1525-1470.2005.00125.x.

6. Laude TA. Approach to dermatologic disorders in black children. Semin Dermato.1995;14(1):15-20. doi: 10.1016/s1085-5629(05)80034-3.

7. Roger M, Barnetson RS. Diseases of skin. In: Campbell AGM, Mcintosh N, editors. Fortar and Arneil's Textbook of pediatrics. 5th ed. New York, NY: Churchil Levingstone; 1998. p. 1633-1635.

8. Bechelli LM, Haddad N, Pimenta WP, Pagnano PM, Melchior E Jr, Fregnan RC, et al. Epidemiological survey of skin diseases in schoolchildren living in the Purus Valley (Acr State, amzonia, brazil) Dermatologica 1981;163(1):78-93.

9. Williams H, Stewart A, Von Mutius E, Cookson W, Anderson HR. Is eczema really on the increase worldwide? J Allergy Clin Immunol. 2008;121(4):947954. doi: https://doi.org/10.1016/j.jaci.2007.11.004.

10. Yoshio H, Lagercrantz H, Gumundsson GH Agerberth B. First line of defense in early human life; Semin Perinatol 2004;28(4);304-311. doi: https://doi.org/ 10. 1053/j. semperi.2004.08.008.

11. Patel JK, Vyas AP, Berman B, Vierra M. Incidence of childhood dermatosis in India. Skinmed. 2010; 8(3): 136-142.
12. Bhatia V. Extent and pattern of paediatric dermatoses in rural areas of central India. Indian J Dermatol Venereol Leprol. 1997;63(1):22-25.

13. Ghosh SK, Saha DK, Roy AK. A clinic aetiological study of dermatoses in pediatric age group. Indian $\mathrm{J}$ Dermatol. 1995; 40:29-31.

14. Sharma RC, Mendiratta V. Clinical profile of cutaneous infections and infestations in paediatric age group. Indian J Dermatol. 1999;44(4):174-178.

15. Ben Saif GA, Al Shehab SA. Pattern of Childhood Dermatoses at a Teaching Hospital of Saudi Arabia. Int J Health Sci (Qassim). 2008; 2:63-74.

16. Sacchidanand S, Sahana MS, Asha GS, Shilpa K. Patternof pediatric dermatoses at a referral centre. Indian J Pediatr. 2014;81(4):375-380. doi: 10.1007/s12098-0120904-8. Epub 2012 Nov 6.

17. Karthikeyan K, Thappa DM, Jeevankumar B. Pattern ofpediatric dermatoses in a referral center in South India. Indian Pediatr. 2004;41(4):373-377.

18. Saurabh S, Sahu SK, Sadishkumar A, Kakkanattu JC, Prapath I, Ralte IL, et al. Screening for skin diseases among primary school children in a rural area of Puducherry. Indian J Dermatol Venereol Leprol. 2013; 79(2):268. doi: 10.4103/0378-6323.107664.

19. Sterling JC, Kurtz JB. Viral infections. In: Champion RH, Burton JL, Burns DA, Breathnach SM, editors. Textbook of Dermatology. 6th ed., Vol. 4. New York: Blackwell Science; 1998. p. 995-1095.

20. Chen GY, Cheng YW, Wang CY, Hsu TJ, Hsu MM, Yang PT, et al. Prevalence of skin diseases among schoolchildren in Magong, Penghu, Taiwan: A community-based clinical survey. J Formos Med Assos. 2008; 107(1):21-29. doi: 10.1016/S0929-6646(08)600042.

21. Wenk C, Itin PH. Epidemiology of pediatric dermatology and allergology in the region of Aargau, Switzerland. Pediatr Dermatol. 2003;20(6):482-487.

22. Yahya $\mathrm{H}$. Change in pattern of skin disease in Kaduna, north-central Nigeria. Int J Dermatol 2007;46(9):936-943. doi: https://doi.org/10.1111/j.1365-4632.2007.03218.x.

\section{How to cite this article?}

Shah A., Sharma P., Bhati S.S., Tomar A., Jain S. Spectrum of infectious dermatoses in pediatric population attending tertiary care centers in Central India: an observational study. Int J Pediatr Res.2019; 6(11): 567-571.doi:10.17511/ijpr.2019.i11.03 